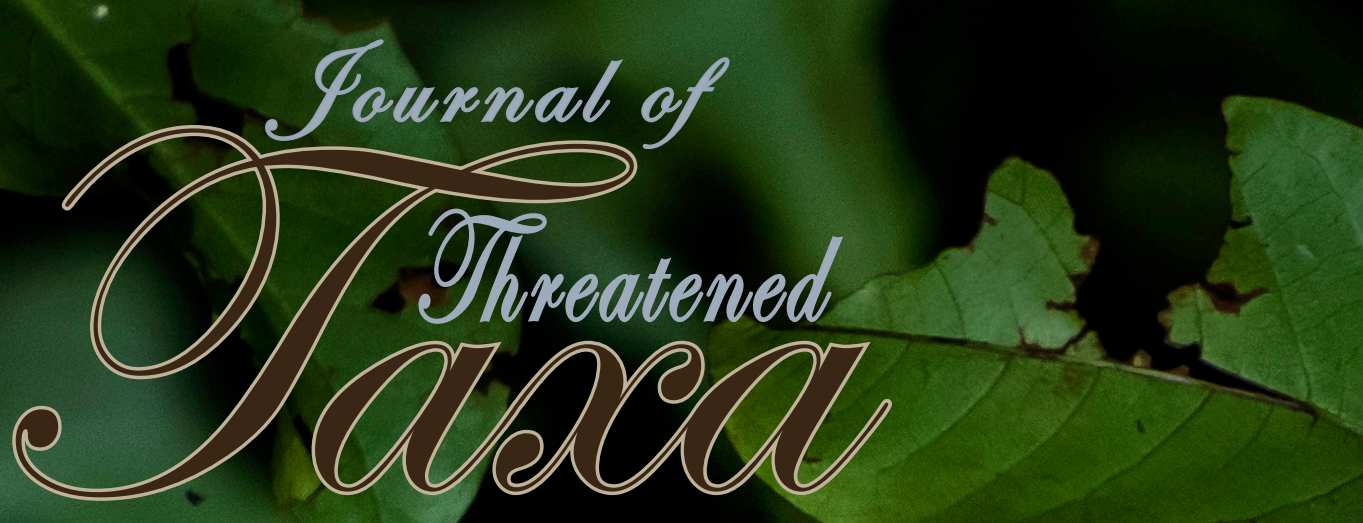

Building exidence for conservation glabally

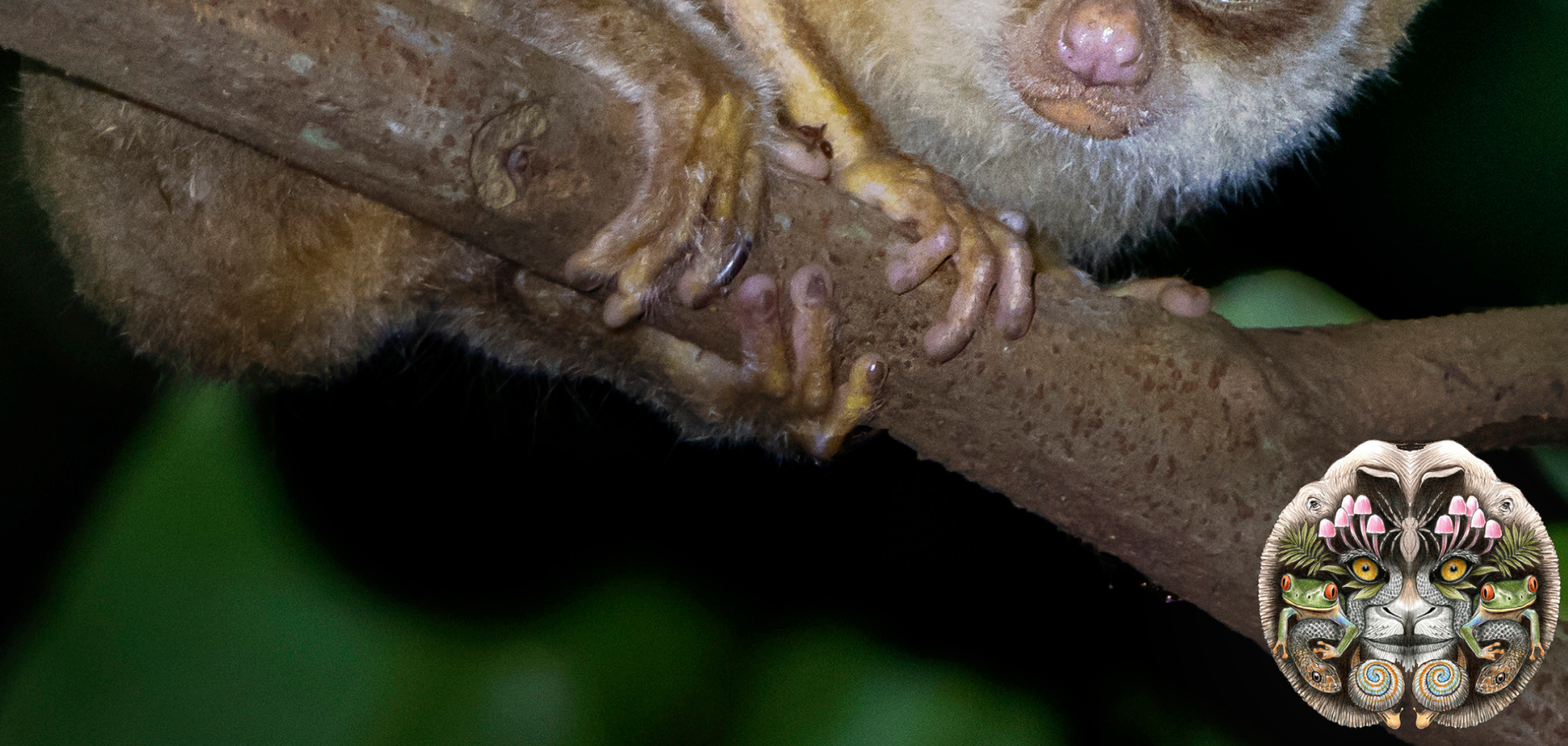

Open Access

$10.11609 /$ jott.2021.13.010.19431-19614 creven.threatenedtaxa.arg

26 September 2021 (Online \& Print) Val. 13 | Na. 11 | Pages: 19431-19674 


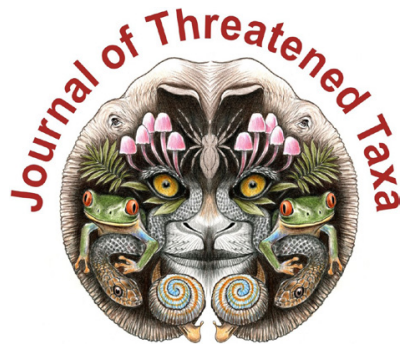

ISSN 0974-7907 (Online); ISSN $0974-7893$ (Print)

Publisher

Host

Wildlife Information Liaison Development Society

www.wild.zooreach.org

Zoo Outreach Organization www.zooreach.org

No. 12, Thiruvannamalai Nagar, Saravanampatti - Kalapatti Road, Saravanampatti, Coimbatore, Tamil Nadu 641035, India

Ph: +91 9385339863 | www.threatenedtaxa.org

Email: sanjay@threatenedtaxa.org

EDITORS

\section{Founder \& Chief Editor}

Dr. Sanjay Molur

Wildlife Information Liaison Development (WILD) Society \& Zoo Outreach Organization (ZOO)

12 Thiruvannamalai Nagar, Saravanampatti, Coimbatore, Tamil Nadu 641035, India

\section{Deputy Chief Edito}

Dr. Neelesh Dahanukar

Noida, Uttar Pradesh, India

\section{Managing Editor}

Mr. B. Ravichandran, WILD/ZOO, Coimbatore, India

\section{Associate Editors}

Dr. Mandar Paingankar, Government Science College Gadchiroli, Maharashtra 442605, India

Dr. Ulrike Streicher, Wildlife Veterinarian, Eugene, Oregon, USA

Ms. Priyanka Iyer, ZOO/WILD, Coimbatore, Tamil Nadu 641035, India

Dr. B. A. Daniel, $200 / \mathrm{WILD}$, Coimbatore, Tamil Nadu 641035, India

\section{Editorial Board}

Dr. Russel Mittermeier

Executive Vice Chair, Conservation International, Arlington, Virginia 22202, USA

\section{Prof. Mewa Singh Ph.D., FASc, FNA, FNASc, FNAPsy}

Ramanna Fellow and Life-Long Distinguished Professor, Biopsychology Laboratory, and Institute of Excellence, University of Mysore, Mysuru, Karnataka 570006, India; Honorary Professor, Jawaharlal Nehru Centre for Advanced Scientific Research, Bangalore; and Adjunct Professor, National Institute of Advanced Studies, Bangalore

\section{Stephen D. Nash}

Scientific Illustrator, Conservation International, Dept. of Anatomical Sciences, Health Sciences Center, T-8, Room 045, Stony Brook University, Stony Brook, NY 11794-8081, USA

\section{Dr. Fred Pluthero}

Toronto, Canada

\section{Dr. Priya Davidar}

Sigur Nature Trust, Chadapatti, Mavinhalla PO, Nilgiris, Tamil Nadu 643223, India

\section{Dr. Martin Fisher}

Senior Associate Professor, Battcock Centre for Experimental Astrophysics, Cavendish

Laboratory, JJ Thomson Avenue, Cambridge CB3 OHE, UK

\section{Dr. John Fellowe}

Honorary Assistant Professor, The Kadoorie Institute, 8/F, T.T. Tsui Building, The University of Hong Kong, Pokfulam Road, Hong Kong

\section{Prof. Dr. Mirco Solé}

Universidade Estadual de Santa Cruz, Departamento de Ciências Biológicas, Vice-coordenado do Programa de Pós-Graduação em Zoologia, Rodovia Ilhéus/Itabuna, Km 16 (45662-000)

Salobrinho, Ilhéus - Bahia - Brasil

\section{Dr. Rajeev Raghavan}

Professor of Taxonomy, Kerala University of Fisheries \& Ocean Studies, Kochi, Kerala, India

\section{English Editors}

Mrs. Mira Bhojwani, Pune, India

Dr. Fred Pluthero, Toronto, Canad

Mr. P. Ilangovan, Chennai, India

Web Maintenance

Mrs. Latha G. Ravikumar, ZOO/WILD, Coimbatore, India

\section{Typesetting}

Mr. Arul Jagadish, ZOO, Coimbatore, India

Mrs. Radhika, ZOO, Coimbatore, India

Mrs. Geetha, ZOO, Coimbatore India

\section{Fundraising/Communications}

Mrs. Payal B. Molur, Coimbatore, India

Subject Editors 2018-2020

Fungi

Dr. B. Shivaraju, Bengaluru, Karnataka, India

Dr. R.K. Verma, Tropical Forest Research Institute, Jabalpur, India

Dr. Vatsavaya S. Raju, Kakatiay University, Warangal, Andhra Pradesh, India

Dr. M. Krishnappa, Jnana Sahyadri, Kuvempu University, Shimoga, Karnataka, India

Dr. K.R. Sridhar, Mangalore University, Mangalagangotri, Mangalore, Karnataka, India

Dr. Gunjan Biswas, Vidyasagar University, Midnapore, West Bengal, India

Plants

Dr. G.P. Sinha, Botanical Survey of India, Allahabad, India

Dr. N.P. Balakrishnan, Ret. Joint Director, BSI, Coimbatore, India

Dr. Shonil Bhagwat, Open University and University of Oxford, UK

Prof. D.J. Bhat, Retd. Professor, Goa University, Goa, India

Dr. Ferdinando Boero, Università del Salento, Lecce, Italy

Dr. Dale R. Calder, Royal Ontaro Museum, Toronto, Ontario, Canada

Dr. Cleofas Cervancia, Univ. of Philippines Los Baños College Laguna, Philippines

Dr. F.B. Vincent Florens, University of Mauritius, Mauritius

Dr. Merlin Franco, Curtin University, Malaysia

Dr. V. Irudayaraj, St. Xavier's College, Palayamkottai, Tamil Nadu, India

Dr. B.S. Kholia, Botanical Survey of India, Gangtok, Sikkim, India

Dr. Pankaj Kumar, Kadoorie Farm and Botanic Garden Corporation, Hong Kong S.A.R., China

Dr. V. Sampath Kumar, Botanical Survey of India, Howrah, West Bengal, India

Dr. A.J. Solomon Raju, Andhra University, Visakhapatnam, India

Dr. Vijayasankar Raman, University of Mississippi, USA

Dr. B. Ravi Prasad Rao, Sri Krishnadevaraya University, Anantpur, India

Dr. K. Ravikumar, FRLHT, Bengaluru, Karnataka, India

Dr. Aparna Watve, Pune, Maharashtra, India

Dr. Qiang Liu, Xishuangbanna Tropical Botanical Garden, Yunnan, China

Dr. Noor Azhar Mohamed Shazili, Universiti Malaysia Terengganu, Kuala Terengganu, Malaysia Dr. M.K. Vasudeva Rao, Shiv Ranjani Housing Society, Pune, Maharashtra, India

Prof. A.J. Solomon Raju, Andhra University, Visakhapatnam, India

Dr. Mandar Datar, Agharkar Research Institute, Pune, Maharashtra, India

Dr. M.K. Janarthanam, Goa University, Goa, India

Dr. K. Karthigeyan, Botanical Survey of India, India

Dr. Errol Vela, University of Montpellier, Montpellier, France

Dr. P. Lakshminarasimhan, Botanical Survey of India, Howrah, India

Dr. Larry R. Noblick, Montgomery Botanical Center, Miami, USA

Dr. K. Haridasan, Pallavur, Palakkad District, Kerala, India

Dr. Analinda Manila-Fajard, University of the Philippines Los Banos, Laguna, Philippines

Dr. P.A. Sinu, Central University of Kerala, Kasaragod, Kerala, India

Dr. Afroz Alam, Banasthali Vidyapith (accredited A grade by NAAC), Rajasthan, India

Dr. K.P. Rajesh, Zamorin's Guruvayurappan College, GA College PO, Kozhikode, Kerala, India

Dr. David E. Boufford, Harvard University Herbaria, Cambridge, MA 02138-2020, USA

Dr. Ritesh Kumar Choudhary, Agharkar Research Institute, Pune, Maharashtra, India

Dr. Navendu Page, Wildlife Institute of India, Chandrabani, Dehradun, Uttarakhand, India

Invertebrates

Dr. R.K. Avasthi, Rohtak University, Haryana, India

Dr. D.B. Bastawade, Maharashtra, India

Dr. Partha Pratim Bhattacharjee, Tripura University, Suryamaninagar, India

Dr. Kailash Chandra, Zoological Survey of India, Jabalpur, Madhya Pradesh, India

Dr. Ansie Dippenaar-Schoeman, University of Pretoria, Queenswood, South Africa

Dr. Rory Dow, National Museum of natural History Naturalis, The Netherlands

Dr. Brian Fisher, California Academy of Sciences, USA

Dr. Richard Gallon, llandudno, North Wales, LL30 1UP

Dr. Hemant V. Ghate, Modern College, Pune, India

Dr. M. Monwar Hossain, Jahangirnagar University, Dhaka, Bangladesh

Mr. Jatishwor Singh Irungbam, Biology Centre CAS, Branišovská, Czech Republic

Dr. lan J. Kitching Natural History Museum, Cromwell Road, UK

Dr. George Mathew, Kerala Forest Research Institute, Peechi, India

Dr. John Noyes, Natural History Museum, London, UK

For Focus, Scope, Aims, and Policies, visit https://threatenedtaxa.org/index.php/JoTT/aims_scope
For Article Submission Guidelines, visit https://threatenedtaxa.org/index.php/JoTT/about/submissions
For Policies against Scientific Misconduct, visit https://threatenedtaxa.org/index.php/JoTT/policies_various 


\title{
A preliminary assessment of odonate diversity along the river Tirthan, Great Himalayan National Park Conservation Area, India with reference to the impact of climate change
}

\author{
Amar Paul Singh ${ }^{1}$ (D), Kritish De $^{2}$ (D), Virendra Prasad Uniyal ${ }^{3}$ (D) \& Sambandam Sathyakumar ${ }^{4}$ (D) \\ ${ }^{1-4}$ Wildlife Institute of India, Post Box \#18, Chandrabani, Dehradun Uttarakhand 248001, India. \\ ${ }^{2}$ Department of Bio Sciences, Sri Sathya Sai University for Human Excellence, Gulbarga, Karnataka 585313, India. \\ ${ }^{1}$ amarpaulsingh4@gmail.com (corresponding author), ${ }^{2}$ kritish.de@gmail.com, ${ }^{3}$ uniyalvp@wii.gov.in, ${ }^{4}$ ssk@wii.gov.in
}

\begin{abstract}
A total of 19 species of odonates, including eight species of Anisoptera (dragonflies) and 11 species of Zygoptera (damselflies), were recorded along the Tirthan River, Great Himalayan National Park Conservation Area (GHNPCA), Himachal Pradesh. Among these species, 17 were reported from the area for the first time. With the addition of these new records the number of odonates known from the GHNPCA is increased to 23 species representing 18 genera and eight families. Indothemis carnatica, Agriocnemis femina, and Argiocnemis rubescens are reported for the first time from the western Himalayan region. The study found a significant change in the species composition of odonates over a period of 18 years in the area, which may be due to changes in microhabitat conditions associated with climate change.
\end{abstract}

Keywords: Dragonfly, damselfly, GHNPCA, Himachal Pradesh, new records, western Himalaya.

Globally, 6,256 species in 686 genera of odonates (order Odonata) are known (Paulson \& Schorr 2020) and most of them are restricted to the tropics, especially to forests, where the group has the greatest diversity (Kalkman et al. 2008). The Odonata of India is represented by 488 species and 27 subspecies in 154 genera and 18 families (Kalkman et al. 2020). The suborder Zygoptera (Damselflies) comprise 211 species in 59 genera \& nine families; Anisozygoptera one species in one genus \& one family; and Anisoptera (Dragonflies) 276 species in 94 genera \& eight families (Subramanian \& Babu 2017).

The odonates are among the most effective bioindicators of environmental health (Kutcher \& Bried 2014; Miguel et al. 2017), and can be used to assess water quality (Kutcher \& Bried 2014), changes in the habitat structure (Yang et al. 2017), success of wetland restoration (D'Amico et al. 2004), ecological condition of streams (de Oliveira-Junior et al. 2015), and environmental quality (Júnior et al. 2015). Odonate diversity of Himachal Pradesh has been studied by various authors (Kumar 1982, 2000; Uniyal et al. 2000; Babu \& Mehta 2009; Babu \& Nandy 2010; Babu \& Mitra 2011; Subramanian \& Babu 2018). Uniyal et al. (2000) reported six species of dragonflies from the Great Himalayan National Park.

The Great Himalayan National Park Conservation Area (GHNPCA) is a World Heritage site designated by UNESCO, situated in Kullu district of Himachal Pradesh and traversed by three tributaries of river Beas-Tirthan, Parvati, and Sainj. The Park extends from the Himalayan foothills to the alpine zone ranging from $1,300 \mathrm{~m}$ to $6,000 \mathrm{~m}$ of altitudinal gradient. The present study was

Citation: Singh, A.P., K. De, V.P. Uniyal \& S. Sathyakumar (2021). A preliminary assessment of odonate diversity along the river Tirthan, Great Himalayan National Park Conservation Area, India with reference to the impact of climate change. Journal of Threatened Taxa 13(11): 19611-19615. https://doi.org/10.11609/ jott.5427.13.11.19611-19615

Copyright: (C) Singh et al. 2021. Creative Commons Attribution 4.0 International License. JoTT allows unrestricted use, reproduction, and distribution of this article in any medium by providing adequate credit to the author(s) and the source of publication.

Funding: The study was carried out with the financial support given to Wildlife Institute of India from Department of Science and Technology under National mission for Sustaining the Himalayan Ecosystem (DST-NMSHE) (DST Grant Number: DST/SPLICE/CCP/NMSHE/TF-2/WII/2014[G]).

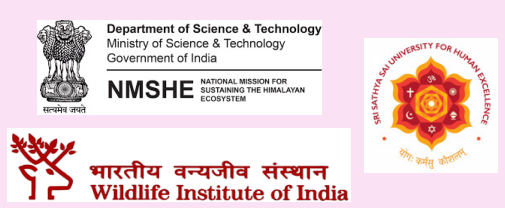

Acknowledgements: Authors are thankful to Director and Dean, Wildlife Institute of India, Dehradun for providing necessary facilities to carry out the work. Authors are also thankful of Mr. Nikhil Singh Kahera for his help during the field work. 

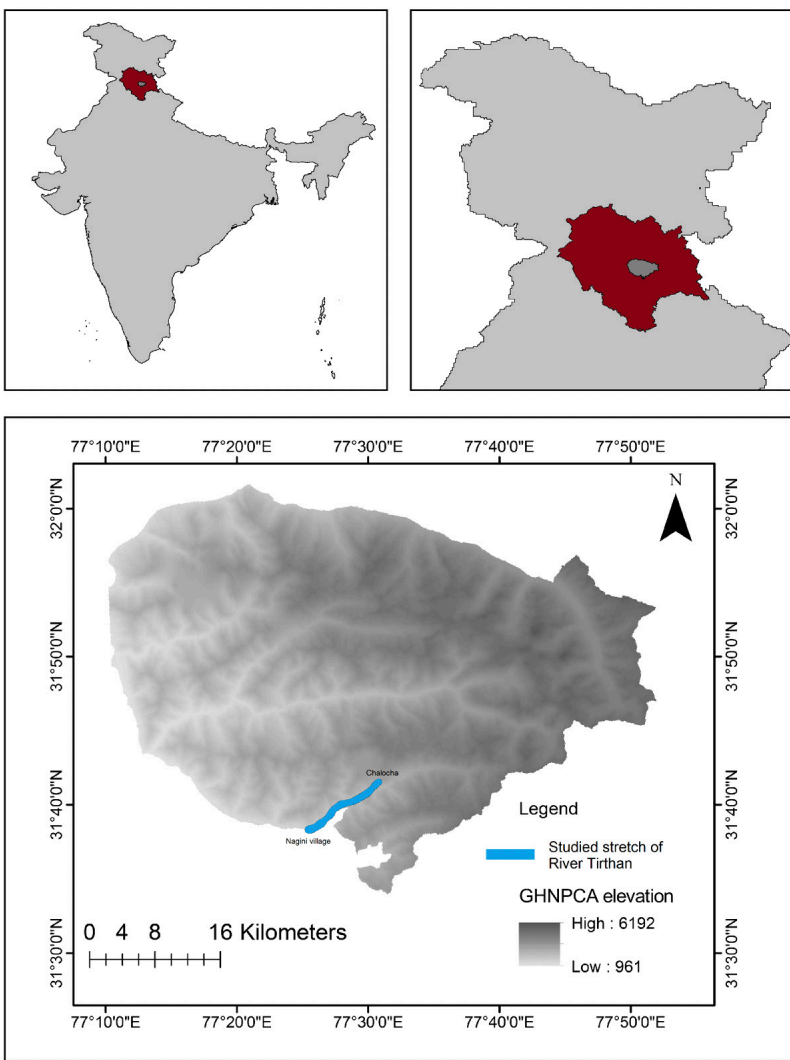

Figure 1. Map represents the studied stretch of Tirthan River, GHNPCA, Himachal Pradesh.

carried out in order to update our understanding of the diversity of odonates in the GHNPCA and to assess the changes of species composition, if any, over the period of 18 years since the previous survey (Uniyal et al. 2000).

\section{MATERIALS AND MethodS}

The work was carried out along a length of about $28 \mathrm{~km}$ of the river Tirthan (a tributary of Beas River), from Nagini village (31.640 lat. 77.398 long., $1,475 \mathrm{~m}$ to Chalocha (31.685 lat., 77.513 long., 2,450m) monthly from June to December, 2018. The area lies near the boundary within the GHNPCA (Figure 1) located in the western Himalaya in the state of Himachal Pradesh. It was declared as a national park in 1999 and a world heritage site by UNESCO in 2014. The area comes under the 'Western Himalayan broadleaf forests' ecoregion (UNESCO 2020).

We surveyed odonate diversity following the methods of Giugliano et al. (2012). Adults were surveyed between $0930 \mathrm{~h}$ and $0500 \mathrm{~h}$ by walking slowly along the edge of the water body three times a month; and with the help of binoculars notes were made of all species observed. Most species were identified without capture. When necessary, a telescopic sweep net was used to catch odonates for identification. Species were identified using published literature (Andrew et al. 2008; Subramaniam 2009; Nair 2011) and web resources (Joshi et al. 2019).

\section{RESULTS AND DISCUSSION}

A total of 19 species of odonates representing 16 genera were recorded; these comprised eight species of dragonflies (Anisoptera) and 11 species of damselflies (Zygoptera) (Table 1, Image 1-19). Among the dragonflies, the family Libellulidae was represented by six species in four genera, and the families Aeshnidae and Gomphidae by one species each (Figure 2). Among the damselflies, the family Coenagrionidae was represented by five species in four genera, the families Chlorocyphidae and Platycnemididae by two species each, and the families Lestidae and Calopterygidae by only one species each (Figure 2).

Among these odonates, one dragonfly Indothemis carnatica Fabricius, 1798 and two damselflies, namely, Agriocnemis femina Brauer, 1868 and Argiocnemis rubescens Selys, 1877, are reported for the first time from Himachal Pradesh, these being the westernmost records in the Himalaya. Rank abundance tests revealed that Libellulidae was the dominant family in the river followed by Coenagrionidae and Lestidae was the least dominant family (Figure 3 ).

Uniyal et al. (2000) reported the presence of six species of odonates from the GHNPCA. The present study reports another 17 species from the area which increases the total number of odonate species from the area to 23 species in 18 genera and eight families. The present study failed to register Anax guttatus, Orthetrum japonicum, Pantala flavescens, and Sympetrum commixtum, which were recorded from the area by Uniyal et al. (2000). The present work reported Indothemis carnatica, Agriocnemis femina, and Argiocnemis rubescens for the first time from the western Himalayan region, these species having previously been reported from the east within the Himalayan region (Subramanian \& Babu 2018), however, Indothemis carnatica was previously reported from Andaman \& Nicobar Island, Maharashtra, Goa, Karnataka, Kerala, Tamil Nadu, Andhra Pradesh, Odisha, West Bengal (Subramanian et al. 2018; Payra et al. 2020) and has been recently recorded from Punjab (Singh et al. 2021).

Compared with Uniyal et al. (2000) that recorded six species, the present study was conducted more systematically along $28 \mathrm{~km}$ of the Tirthan River using standardised methods. Grassy, stagnant water, running water, and rocky habitats were preferred by different species (Image 20 and 21). Orthetrum triangulare and Orthetrum taeniolatum were the most common species found throughout the stretch from 1,475 m elevation 
Table 1. List of odonates recorded from Tirthan River, Great Himalayan National Park Conservation Area.

\begin{tabular}{|c|c|c|c|c|}
\hline & Family & Scientific name & $\begin{array}{l}\text { Elevation } \\
\text { range }(\mathrm{m})\end{array}$ & $\begin{array}{c}\text { No. of } \\
\text { individuals } \\
\text { observed }\end{array}$ \\
\hline & \multicolumn{4}{|c|}{ Anisoptera } \\
\hline 1 & Aeshnidae & $\begin{array}{l}\text { Anax nigrofasciatus } \\
\text { Oguma, } 1915\end{array}$ & $1475-1700$ & 8 \\
\hline 2 & Gomphidae & \begin{tabular}{|l|} 
Paragomphus lineatus \\
(Selys, 1850)
\end{tabular} & $1475-1600$ & 12 \\
\hline 3 & Libellulidae & \begin{tabular}{|l|} 
Crocothemis servilia \\
(Drury, 1773)
\end{tabular} & $1475-1700$ & 18 \\
\hline 4 & & \begin{tabular}{|l} 
Indothemis carnatica \\
(Fabricius, 1798) \\
\end{tabular} & $1475-2000$ & 26 \\
\hline 5 & & \begin{tabular}{|l|}
$\begin{array}{l}\text { Orthetrum pruinosum } \\
\text { (Burmeister, 1839) }\end{array}$ \\
\end{tabular} & $1475-1700$ & 22 \\
\hline 6 & & \begin{tabular}{|l|} 
Orthetrum taeniolatum \\
(Schneider, 1845)
\end{tabular} & $1475-2450$ & 25 \\
\hline 7 & & $\begin{array}{l}\text { Orthetrum triangulare } \\
\text { (Selys, 1878) }\end{array}$ & $1475-2450$ & 38 \\
\hline \multirow[t]{2}{*}{8} & & $\begin{array}{l}\text { Palpopleura sexmaculata } \\
\text { (Fabricius, 1787) }\end{array}$ & $1475-1700$ & 4 \\
\hline & \multicolumn{4}{|c|}{ Zygoptera } \\
\hline 9 & Coenagrionidae & $\begin{array}{l}\text { Agriocnemis femina } \\
\text { (Brauer, 1868) }\end{array}$ & $1475-1600$ & 2 \\
\hline 10 & & $\begin{array}{l}\text { Amphiallagma parvum } \\
\text { (Selys, 1876) }\end{array}$ & $1475-1700$ & 6 \\
\hline 11 & & \begin{tabular}{|l} 
Ceriagrion \\
coromandelianum \\
(Fabricius, 1798) \\
\end{tabular} & $1475-1700$ & 35 \\
\hline 12 & & \begin{tabular}{|l} 
Ischnura forcipata \\
Morton, 1907
\end{tabular} & $1475-1700$ & 18 \\
\hline 13 & & $\begin{array}{l}\text { Ischnura rubilio Selys, } \\
1876\end{array}$ & $1475-1600$ & 2 \\
\hline 14 & Chlorocyphidae & $\begin{array}{l}\text { Aristocypha } \\
\text { quadrimaculata (Selys, } \\
1853 \text { ) }\end{array}$ & $1475-2000$ & 2 \\
\hline 15 & & $\begin{array}{l}\text { Libellago lineata } \\
\text { (Burmeister, 1839) }\end{array}$ & $1475-1700$ & 2 \\
\hline 16 & Calopterygidae & $\begin{array}{l}\text { Neurobasis chinensis } \\
\text { (Linnaeus, 1758) }\end{array}$ & 1475 & 4 \\
\hline 17 & Lestidae & $\begin{array}{l}\text { Indolestes cyaneus } \\
\text { (Selys,1862) }\end{array}$ & 1495 & 1 \\
\hline 18 & Platycnemididae & $\begin{array}{l}\text { Calicnemia eximia (Selys, } \\
1863 \text { ) }\end{array}$ & $1475-1600$ & 32 \\
\hline 19 & & $\begin{array}{l}\text { Copera vittata (Selys, } \\
1863 \text { ) }\end{array}$ & $1475-1700$ & 6 \\
\hline
\end{tabular}

up to $2,450 \mathrm{~m}$. There was higher species richness at lower elevations. Calicnemia eximia, Ischnura rubilio, and Agriocnemis femina preferred grassy habitat near the banks of stagnant ponds at a lower elevation range from 1,475-1,600 m. Anax nigrofasciatus, Crocothemis servilia, Orthetrum pruinosum, Orthetrum triangulae, Amphiallagma parvum, Ceriagrion coromandelianum, Ischnura forcipate, Palpopleura sexmaculata, Libellago lineata, and Copera vittata were found at stagnant or slow running grassy water channels from 1,475-1,700 m. Indolestes cyaneus was very rare in the region and was found away from the river under forest canopy cover at an elevation of 1,495 m. Aristocypha quadrimaculata

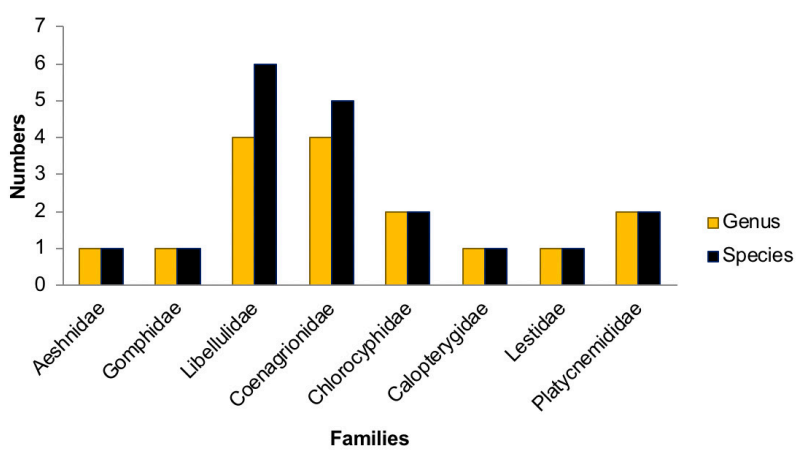

Figure 2. Comparative numbers of genera and species of odonates under eight families recorded from Tirthan River, Great Himalayan National Park Conservation Area.

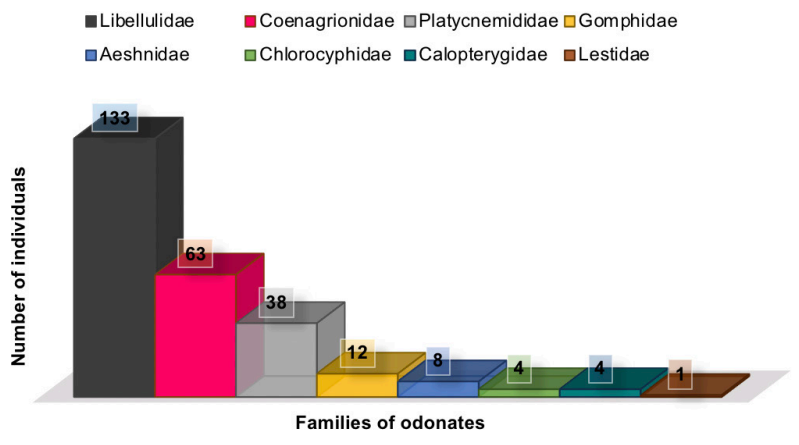

Figure 3. Rank abundance of odonate families along the Tirthan River of Great Himalayan National Park Conservation Area.

and Indothemis carnatica preferred rocky water channels from 1,475-2,000 m. However, Paragomphus lineatus was found in agricultural areas near the river from 1,475$1,600 \mathrm{~m}$ and Neurobasis chinensis was collected from fast running water at $1,475 \mathrm{~m}$.

The Himalayan ecosystem is a sensitive and fragile ecosystem with rich biodiversity that provides major ecosystem services (Kumar et al. 2019). As climate change phenomena become a threat to this ecosystem, monitoring climatic indicator species helps us understand the change of ecosystem functions caused by climate change. Odonates have for some time been used successfully as model organisms to study climate change (Hassall \& Thompson 2008; Parr 2010; Jaeschke et al. 2013; Bush et al. 2014; Hassall 2015; Termaat et al. 2019). Studies by Flenner \& Sahlén (2008) has shown that species composition and abundance may change over as short a time span as 10 years due to environmental changes as dragonflies react rapidly to climate change. The present study found significant changes in the odonate species composition relative to that found by Uniyal et al. (2000), as only two species were re-recorded with the addition of 17 new species to the region. These changes in species 

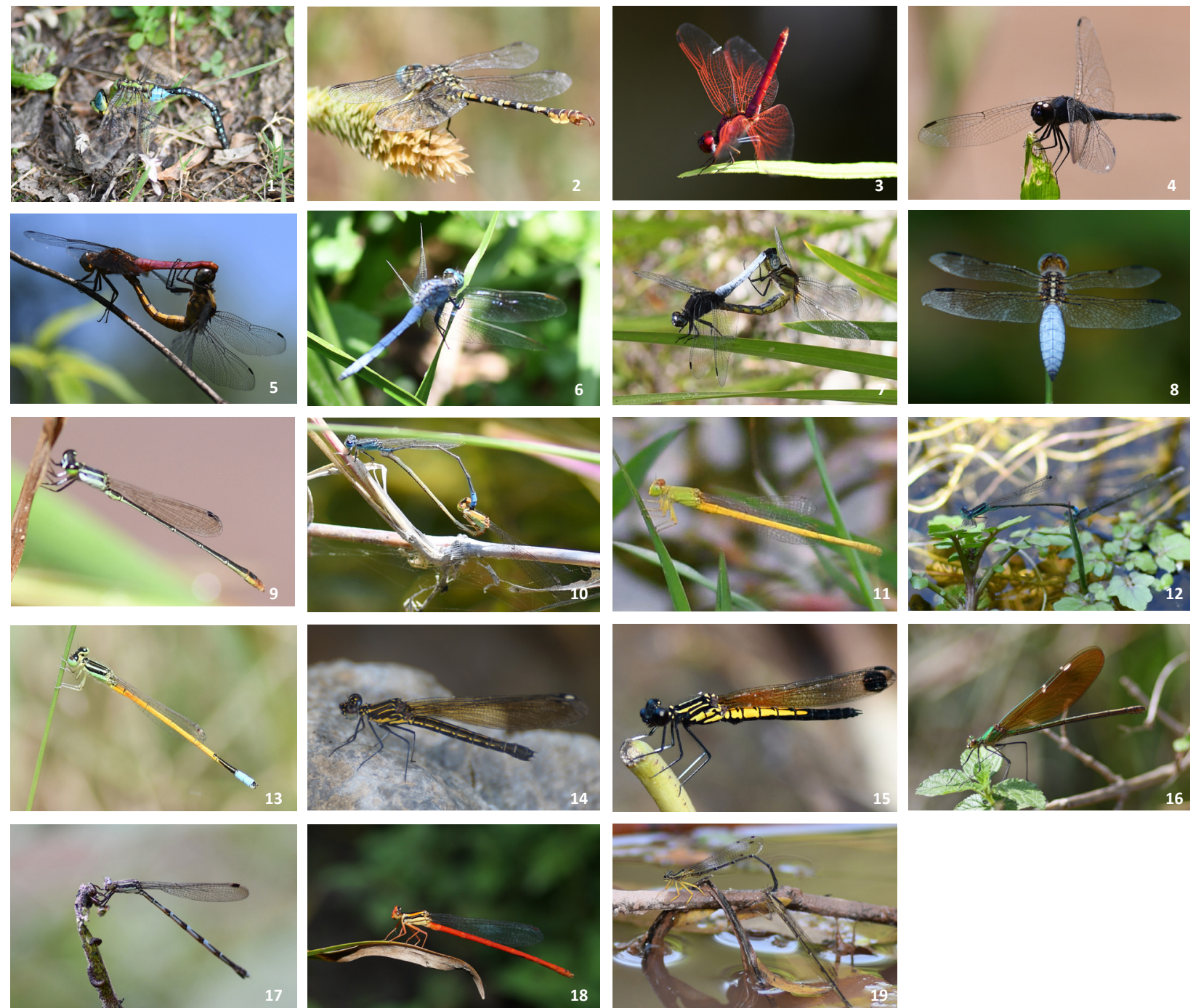

Images 1-19: 1-Anax nigrofasciatus | 2-Paragomphus lineatus | 3-Crocothemis servilia | 4-Indothemis carnatica | 5-Orthetrum pruinosum | 6-Orthetrum taeniolatum | 7-Orthetrum triangulare | 8-Palpopleura sexmaculata | 9-Agriocnemis femina | 10Amphiallagma parvum | 11-Ceriagrion coromandelianum | 12-Ischnura forcipata | 13-Ischnura rubilio | 14-Aristocypha quadrimaculata | 15-Libellago lineata | 16-Neurobasis chinensis | 17-Indolestes cyaneus | 18-Calicnemia eximia | 19-Copera vittata. @ Amar Paul Singh

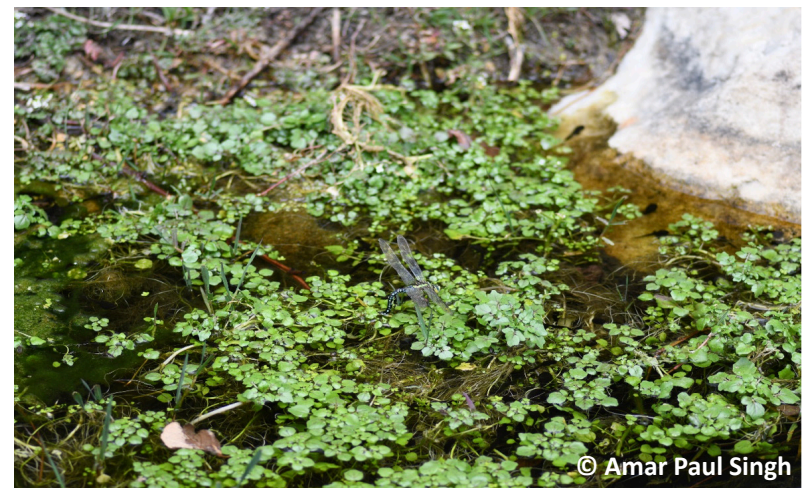

Image 20. Anax nigrofasciatus in stagnant and grassy water habitat.

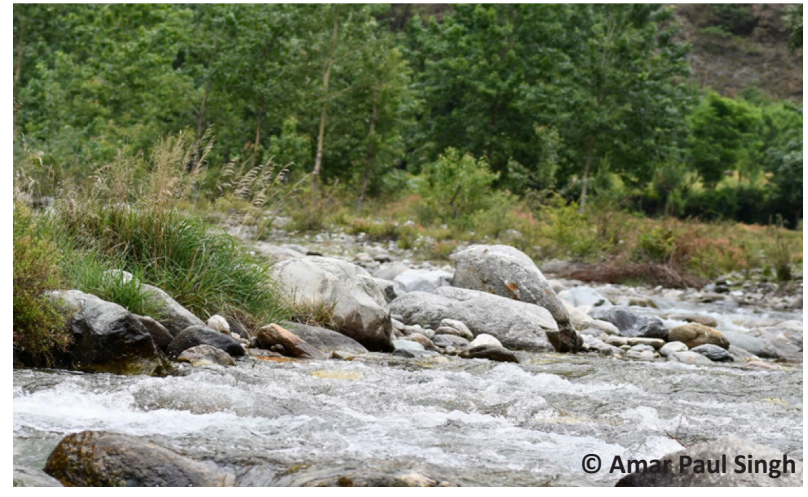

Image 21. Rocky, grassy, and fast running water habitat. 
composition may have occurred because of changes in microhabitat factors due to climate changes in the Himalayan region or due to the sampling efforts in the region.

Dragonflies have been shown to be useful for ecosystem monitoring and conservation, and recently an increased effort is being made to make information on dragonflies available to both scientists and policymakers (Kalkman et al. 2008). So, it is indispensable to document the status of diversity and ecology of odonates as well as other entomofauna from the Great Himalayan National Park Conservation Area to understand changing ecological conditions in the context of climate change.

\section{REFERENCES}

Andrew, R.J., K.A. Subramaniam \& A.D. Tiple (2008). Common Odonates of Central India. E-book for "The $18^{\text {th }}$ International Symposium of Odonatology", Hislop College, Nagpur, India, 50pp.

Babu, R. \& H.S. Mehta (2009). Insecta: Odonata, pp. 21-28. In: Fauna Diversity of Simbalbara Wildlife Sanctuary. Conservation Area Series No. 41. Zoological Survey of India, Kolkata.

Babu, R. \& A. Mitra (2011). A record of Gomphidia t-nigrum Selys from Himachal Pradesh, India (Anisoptera: Gomphidae). Notulae odonatologicae 7(8): 75-76.

Babu, R. \& S. Nandy (2010). New Odonata records from Himachal Pradesh, India. Notulae odonatologicae 7(6): 55-57.

Bush, A.A., D.A. Nipperess, D.E. Duursma, G. Theischinger, E. Turak \& L. Hughes (2014). Continental-scale assessment of risk to the Australian Odonata from climate change. PloS One 9(2): p.e88958. https://doi. org/10.1371/journal.pone.0088958

D’Amico, F., S. Darblade, S. Avignon, S. Blanc-Manel \& S.J. Ormerod (2004). Odonates as indicators of shallow lake restoration by liming: comparing adult and larval responses. Restoration Ecology 12(3): 439-446. https://doi.org/10.1111/j.1061-2971.2004.00319.x

de Oliveira-Junior, J.M.B., Y. Shimano, T.A. Gardner, R.M. Hughes, P. de Marco Júnior \& L. Juen (2015). Neotropical dragonflies (Insecta: Odonata) as indicators of ecological condition of small streams in the eastern Amazon. Austral Ecology 40(6): 733-744. https://doi. org/10.1111/aec.12242

Flenner, I.D.A. \& G. Sahlén (2008). Dragonfly community re-organisation in boreal forest lakes: rapid species turnover driven by climate change? Insect Conservation and Diversity 1(3): 169-179. https://doi. org/10.1111/j.1752-4598.2008.00020.x

Giugliano, L., S. Hardersen \& G. Santini (2012). Odonata communities in retrodunal ponds: a comparison of sampling methods. International Journal of Odonatology 15(1): 13-23. https://doi.org/10.1080/13887 890.2012.660403

Hassall, C. \& D.J. Thompson (2008). The effects of environmental warming on Odonata: a review. International Journal of Odonatology 11(2): 31-153. https://doi.org/10.1080/13887890.2008.9748319

Hassall, C. (2015). Odonata as candidate macroecological barometers for global climate change. Freshwater Science 34(3): 1040-1049. https://doi.org/10.1086/682210

Jaeschke, A., T. Bittner, B. Reineking \& C. Beierkuhnlein (2013). Can they keep up with climate change?-Integrating specific dispersal abilities of protected Odonata in species distribution modelling. Insect Conservation and Diversity 6(1): 93-103. https://doi.org/10.1111/ j.1752-4598.2012.00194.x

Joshi, S., P. Dawn, P. Roy \& K. Kunte (eds.) (2019). Odonata of India, v. 1.48. Indian Foundation for Butterflies. https://www.indianodonata. org/ Accession Date: 02/06/2019

Júnior, C.D.S.M., L. Juen \& N. Hamada (2015). Analysis of urban impacts on aquatic habitats in the central Amazon basin: adult odonates as bioindicators of environmental quality. Ecological Indicators 48: 303311. https://doi.org/10.1016/j.ecolind.2014.08.021

Kalkman, V.J., V. Clausnitzer, K.D.B. Dijkstra, A.G. Orr, D.R. Paulson \& J. van Tol (2008). Global diversity of dragonflies (Odonata) in freshwater. Hydrobiologia 595: 351-363. https://doi.org/10.1007/ s10750-007-9029-x

Kalkman V.J., R. Babu, M. Bedjanič, K. Conniff, T. Gyeltshen, M.K. Khan, K.A. Subramanian, A. Zia \& A.G. Orr (2020). Checklist of the dragonflies and damselflies (Insecta: Odonata) of Bangladesh, Bhutan, India, Nepal, Pakistan and Sri Lanka. Zootaxa 4849(1): 001084. https://doi.org/10.11646/zootaxa.4849.1.1

Kumar, A. (1982). An annotated list of Odonata of Himachal Pradesh. Indian Journal of Physical and Natural Sciences 2(A): 55-59.

Kumar, A. (2000). Odonata, pp. 45-53. In: Fauna of Renuka Wetland (Western Himalaya: Himachal Pradesh). Wetland Ecosystem Series No. 2. Zoological Survey of India, Calcutta.

Kumar, M., H. Singh, R. Pandey, M.P. Singh, N.H. Ravindranath \& N. Kalra (2019). Assessing vulnerability of forest ecosystem in the Indian Western Himalayan region using trends of net primary productivity. Biodiversity and Conservation 28(8-9): 2163-2182. https://doi. org/10.1007/s10531-018-1663-2

Kutcher, T.E. \& J.T. Bried (2014). Adult Odonata conservatism as an indicator of freshwater wetland condition. Ecological Indicators 38: 31-39. https://doi.org/10.1016/j.ecolind.2013.10.028

Nair, M.V. (2011). Dragonflies \& Damselflies of Orissa and Eastern India. Wildlife Organisation, Forest \& Environment Department, Government of Orissa, 252pp.

Parr, A. (2010). Monitoring of Odonata in Britain and possible insights into climate change. BioRisk 5: 127. https://doi.org/10.3897/ biorisk. 5.846

Paulson, D. \& M. Schorr (2020). World Odonata List. https://www. pugetsound.edu/academics/academic-resources/slater-museum/ biodiversity-resources/dragonflies/world-odonata-list2 Accession date: $28 / 07 / 2019$

Payra, A., S.K. Dash, H.S. Palei, A.D. Tiple, A.K. Mishra, R.K. Mishra \& S.D. Rout (2020). An updated list of Odonata species from Athgarh Forest Division, Odisha, eastern India (Insecta: Odonata). Mongolian Journal of Biological Sciences 18(1): 55-64.

Singh, A.P., A. Chandra, V.P. Uniyal \& B.S. Adhikari (2021). Catalogue of selected insect groups of Lalwan Community Reserve and Ranjit Sagar Conservation Reserve, Punjab, India. Journal of Threatened Taxa 13(3): 18020-18029. https://doi.org/10.11609/jott.5669.13.3.1802018029

Subramaniam, K.A. (2009). Dragonflies of India: A Field Guide. Vigyan Prasar, Noida, 168pp.

Subramanian, K.A., K.G. Emiliyamma, R. Babu, C. Radhakrishnan \& S.S. Talmale (2018). Atlas of Odonata (Insecta) of the Western Ghats. Zoological Survey of India, Kolkata, 417pp.

Subramanian, K.A. \& R. Babu (2018). Insecta: Odonata, pp. 227-240. In: Faunal Diversity of Indian Himalaya. Zoological Survey India, Kolkata.

Subramanian, K.A. \& R. Babu (2017). Checklist of Odonata (Insecta) of India. Version 3.0. https://www.zsi.gov.in/WriteReadData/userfiles/ file/Checklist/Odonata\%20V3.pdf. Accession date: 24/06/2019

Termaat, T., A.J. van Strien, R.H. van Grunsven, G. De Knijf, U. Bjelke, K. Burbach, K.J. Conze, P. Goffart, D. Hepper, V.J. Kalkman \& G. Motte (2019). Distribution trends of European dragonflies under climate change. Diversity and Distributions 25(6): 936-950. https://doi. org/10.1111/ddi.12913

UNESCO (2020). Great Himalayan National Park Conservation Area. https://whc.unesco.org/en/list/1406/

Uniyal, V.P., A. Mitra \& P.K. Mathur (2000). Dragonfly fauna (Insecta: Odonata) in Great Himalayan National Park, western Himalaya. Annals of Forestry 8(1): 116-119.

Yang, G., Z. Li \& C. Fan (2017). The effect of ecological rehabilitation of the Erhai lake side on Odonata species richness and abundance. Aquatic Insects 38(4): 231-238. https://doi.org/10.1080/01650424.2 017.1414851 

Dr. Albert G. Orr, Griffith University, Nathan, Australia

Dr. Sameer Padhye, Katholieke Universiteit Leuven, Belgium

Dr. Nancy van der Poorten, Toronto, Canada

Dr. Kareen Schnabel, NIWA, Wellington, New Zealand

Dr. R.M. Sharma, (Retd.) Scientist, Zoological Survey of India, Pune, India

Dr. Manju Siliwal, WILD, Coimbatore, Tamil Nadu, India

Dr. G.P. Sinha, Botanical Survey of India, Allahabad, India

Dr. K.A. Subramanian, Zoological Survey of India, New Alipore, Kolkata, India

Dr. P.M. Sureshan, Zoological Survey of India, Kozhikode, Kerala, India

Dr. R. Varatharajan, Manipur University, Imphal, Manipur, India

Dr. Eduard Vives, Museu de Ciències Naturals de Barcelona, Terrassa, Spain

Dr. James Young, Hong Kong Lepidopterists' Society, Hong Kong

Dr. R. Sundararaj, Institute of Wood Science \& Technology, Bengaluru, India

Dr. M. Nithyanandan, Environmental Department, La Ala Al Kuwait Real Estate. Co. K.S.C., Kuwait

Dr. Himender Bharti, Punjabi University, Punjab, India

Mr. Purnendu Roy, London, UK

Dr. Saito Motoki, The Butterfly Society of Japan, Tokyo, Japan

Dr. Sanjay Sondhi, TITLI TRUST, Kalpavriksh, Dehradun, India

Dr. Nguyen Thi Phuong Lien, Vietnam Academy of Science and Technology, Hanoi, Vietnam

Dr. Nitin Kulkarni, Tropical Research Institute, Jabalpur, India

Dr. Robin Wen Jiang Ngiam, National Parks Board, Singapore

Dr. Lional Monod, Natural History Museum of Geneva, Genève, Switzerland.

Dr. Asheesh Shivam, Nehru Gram Bharti University, Allahabad, India

Dr. Rosana Moreira da Rocha, Universidade Federal do Paraná, Curitiba, Brasil

Dr. Kurt R. Arnold, North Dakota State University, Saxony, Germany

Dr. James M. Carpenter, American Museum of Natural History, New York, USA

Dr. David M. Claborn, Missouri State University, Springfield, USA

Dr. Kareen Schnabel, Marine Biologist, Wellington, New Zealand

Dr. Amazonas Chagas Júnior, Universidade Federal de Mato Grosso, Cuiabá, Brasil

Mr. Monsoon Jyoti Gogoi, Assam University, Silchar, Assam, India

Dr. Heo Chong Chin, Universiti Teknologi MARA (UiTM), Selangor, Malaysia

Dr. R.J. Shiel, University of Adelaide, SA 5005, Australia

Dr. Siddharth Kulkarni, The George Washington University, Washington, USA

Dr. Priyadarsanan Dharma Rajan, ATREE, Bengaluru, India

Dr. Phil Alderslade, CSIRO Marine And Atmospheric Research, Hobart, Australia

Dr. John E.N. Veron, Coral Reef Research, Townsville, Australia

Dr. Daniel Whitmore, State Museum of Natural History Stuttgart, Rosenstein, Germany.

Dr. Yu-Feng Hsu, National Taiwan Normal University, Taipei City, Taiwan

Dr. Keith V. Wolfe, Antioch, California, USA

Dr. Siddharth Kulkarni, The Hormiga Lab, The George Washington University, Washington,

D.C., USA

Dr. Tomas Ditrich, Faculty of Education, University of South Bohemia in Ceske

Budejovice, Czech Republic

Dr. Mihaly Foldvari, Natural History Museum, University of Oslo, Norway

Dr. V.P. Uniyal, Wildlife Institute of India, Dehradun, Uttarakhand 248001, India

Dr. John T.D. Caleb, Zoological Survey of India, Kolkata, West Bengal, India

Dr. Priyadarsanan Dharma Rajan, Ashoka Trust for Research in Ecology and the Environment (ATREE), Royal Enclave, Bangalore, Karnataka, India

\section{Fishes}

Dr. Neelesh Dahanukar, IISER, Pune, Maharashtra, India

Dr. Topiltzin Contreras MacBeath, Universidad Autónoma del estado de Morelos, México

Dr. Heok Hee Ng, National University of Singapore, Science Drive, Singapore

Dr. Rajeev Raghavan, St. Albert's College, Kochi, Kerala, India

Dr. Robert D. Sluka, Chiltern Gateway Project, A Rocha UK, Southall, Middlesex, UK

Dr. E. Vivekanandan, Central Marine Fisheries Research Institute, Chennai, India

Dr. Davor Zanella, University of Zagreb, Zagreb, Croatia

Dr. A. Biju Kumar, University of Kerala, Thiruvananthapuram, Kerala, India

Dr. Akhilesh K.V., ICAR-Central Marine Fisheries Research Institute, Mumbai Research

Centre, Mumbai, Maharashtra, India

Dr. J.A. Johnson, Wildlife Institute of India, Dehradun, Uttarakhand, India

\section{Amphibians}

Dr. Sushil K. Dutta, Indian Institute of Science, Bengaluru, Karnataka, India

Dr. Annemarie Ohler, Muséum national d'Histoire naturelle, Paris, France

\section{Reptiles}

Dr. Gernot Vogel, Heidelberg, Germany

Dr. Raju Vyas, Vadodara, Gujarat, India

Dr. Pritpal S. Soorae, Environment Agency, Abu Dubai, UAE.

Prof. Dr. Wayne J. Fuller, Near East University, Mersin, Turkey

Prof. Chandrashekher U. Rivonker, Goa University, Taleigao Plateau, Goa. India

Dr. S.R. Ganesh, Chennai Snake Park, Chennai, Tamil Nadu, India

Dr. Himansu Sekhar Das, Terrestrial \& Marine Biodiversity, Abu Dhabi, UAE
Birds

Dr. Hem Sagar Baral, Charles Sturt University, NSW Australia

Dr. Chris Bowden, Royal Society for the Protection of Birds, Sandy, UK

Dr. Priya Davidar, Pondicherry University, Kalapet, Puducherry, India

Dr. J.W. Duckworth, IUCN SSC, Bath, UK

Dr. Rajah Jayapal, SACON, Coimbatore, Tamil Nadu, India

Dr. Rajiv S. Kalsi, M.L.N. College, Yamuna Nagar, Haryana, India

Dr. V. Santharam, Rishi Valley Education Centre, Chittoor Dt., Andhra Pradesh, India

Dr. S. Balachandran, Bombay Natural History Society, Mumbai, India

Mr. J. Praveen, Bengaluru, India

Dr. C. Srinivasulu, Osmania University, Hyderabad, India

Dr. K.S. Gopi Sundar, International Crane Foundation, Baraboo, USA

Dr. Gombobaatar Sundev, Professor of Ornithology, Ulaanbaatar, Mongolia

Prof. Reuven Yosef, International Birding \& Research Centre, Eilat, Israel

Dr. Taej Mundkur, Wetlands International, Wageningen, The Netherlands

Dr. Carol Inskipp, Bishop Auckland Co., Durham, UK

Dr. Tim Inskipp, Bishop Auckland Co, Durham, UK

Dr. V. Gokula, National College, Tiruchirappalli, Tamil Nadu, India

Dr. Arkady Lelej, Russian Academy of Sciences, Vladivostok, Russia

Dr. Simon Dowell, Science Director, Chester Zoo, UK

Dr. Mário Gabriel Santiago dos Santos, Universidade de Trás-os-Montes e Alto Douro,

Quinta de Prados, Vila Real, Portugal

Dr. Grant Connette, Smithsonian Institution, Royal, VA, USA

Dr. M. Zafar-ul Islam, Prince Saud Al Faisal Wildlife Research Center, Taif, Saudi Arabia

Mammals

Dr. Giovanni Amori, CNR - Institute of Ecosystem Studies, Rome, Italy

Dr. Anwaruddin Chowdhury, Guwahati, India

Dr. David Mallon, Zoological Society of London, UK

Dr. Shomita Mukherjee, SACON, Coimbatore, Tamil Nadu, India

Dr. Angie Appel, Wild Cat Network, Germany

Dr. P.O. Nameer, Kerala Agricultural University, Thrissur, Kerala, India

Dr. Ian Redmond, UNEP Convention on Migratory Species, Lansdown, UK

Dr. Heidi S. Riddle, Riddle's Elephant and Wildlife Sanctuary, Arkansas, USA

Dr. Karin Schwartz, George Mason University, Fairfax, Virginia.

Dr. Lala A.K. Singh, Bhubaneswar, Orissa, India

Dr. Mewa Singh, Mysore University, Mysore, India

Dr. Paul Racey, University of Exeter, Devon, UK

Dr. Honnavalli N. Kumara, SACON, Anaikatty P.O., Coimbatore, Tamil Nadu, India

Dr. Nishith Dharaiya, HNG University, Patan, Gujarat, India

Dr. Spartaco Gippoliti, Socio Onorario Società Italiana per la Storia della Fauna "Giuseppe

Altobello", Rome, Italy

Dr. Justus Joshua, Green Future Foundation, Tiruchirapalli, Tamil Nadu, India

Dr. H. Raghuram, The American College, Madurai, Tamil Nadu, India

Dr. Paul Bates, Harison Institute, Kent, UK

Dr. Jim Sanderson, Small Wild Cat Conservation Foundation, Hartford, USA

Dr. Dan Challender, University of Kent, Canterbury, UK

Dr. David Mallon, Manchester Metropolitan University, Derbyshire, UK

Dr. Brian L. Cypher, California State University-Stanislaus, Bakersfield, CA

Dr. S.S. Talmale, Zoological Survey of India, Pune, Maharashtra, India

Prof. Karan Bahadur Shah, Budhanilakantha Municipality, Kathmandu, Nepal

Dr. Susan Cheyne, Borneo Nature Foundation International, Palangkaraja, Indonesia

Dr. Hemanta Kafley, Wildlife Sciences, Tarleton State University, Texas, USA

\section{Other Disciplines}

Dr. Aniruddha Belsare, Columbia MO 65203, USA (Veterinary)

Dr. Mandar S. Paingankar, University of Pune, Pune, Maharashtra, India (Molecular)

Dr. Jack Tordoff, Critical Ecosystem Partnership Fund, Arlington, USA (Communities)

Dr. Ulrike Streicher, University of Oregon, Eugene, USA (Veterinary)

Dr. Hari Balasubramanian, EcoAdvisors, Nova Scotia, Canada (Communities)

Dr. Rayanna Hellem Santos Bezerra, Universidade Federal de Sergipe, São Cristóvão, Brazil

Dr. Jamie R. Wood, Landcare Research, Canterbury, New Zealand

Dr. Wendy Collinson-Jonker, Endangered Wildlife Trust, Gauteng, South Africa

Dr. Rajeshkumar G. Jani, Anand Agricultural University, Anand, Gujarat, India

Dr. O.N. Tiwari, Senior Scientist, ICAR-Indian Agricultural Research Institute (IARI), New

Delhi, India

Dr. L.D. Singla, Guru Angad Dev Veterinary and Animal Sciences University, Ludhiana, India

Dr. Rupika S. Rajakaruna, University of Peradeniya, Peradeniya, Sri Lanka

Dr. Bahar Baviskar, Wild-CER, Nagpur, Maharashtra 440013, India

Reviewers 2018-2020

Due to pausity of space, the list of reviewers for 2018-2020 is available online.
The opinions expressed by the authors do not reflect the views of the Journal of Threatened Taxa, Wildlife Information Liaison Development Society, Zoo Outreach Organization, or any of the partners. The journal, the publisher, the host, and the partners are not responsible for the accuracy of the political boundaries shown in the maps by the authors.

\footnotetext{
Print copies of the Journal are available at cost. Write to:

The Managing Editor, JoTT,

c/o Wildlife Information Liaison Development Society,

No. 12, Thiruvannamalai Nagar, Saravanampatti - Kalapatti Road,

Saravanampatti, Coimbatore, Tamil Nadu 641035, India

ravi@threatenedtaxa.org
} 


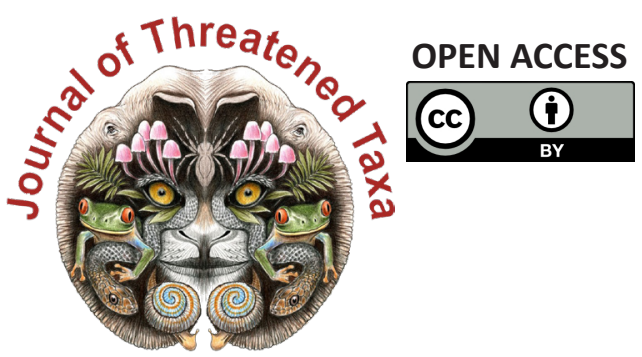

www.threatenedtaxa.org

The Journal of Threatened Taxa (JoTT) is dedicated to building evidence for conservation globally by publishing peer-reviewed articles online every month at a reasonably rapid rate at www.threatenedtaxa.org. All articles published in JoTT are registered under Creative Commons Attribution 4.0 International License unless otherwise mentioned. JoTT allows allows unrestricted use, reproduction, and distribution of articles in any medium by providing adequate credit to the author(s) and the source of publication.

\section{ISSN $0974-7907$ (Online) | ISSN $0974-7893$ (Print)}

\section{September 2021 | Vol. 13 | No. 11 | Pages: 19431-19674 Date of Publication: 26 September 2021 (Online \& Print) DOI: 10.11609/jott.2021.13.11.19431-19674}

Articles

Understanding human-flying fox interactions in the Agusan Marsh Wildlife Sanctuary as basis for conservation policy interventions

- Sherryl L. Paz \& Juan Carlos T. Gonzalez, Pp. 19431-19447

Argentinian odonates (dragonflies and damselflies): current and future distribution and discussion of their conservation

- A. Nava-Bolaños, D.E. Vrech, A.V. Peretti \& A. Córdoba-Aguilar, Pp. 19448-19465

\section{Communications}

The diel activity pattern of small carnivores of Western Ghats, India: a case study at Nelliampathies in Kerala, India

- Devika Sanghamithra \& P.O. Nameer, Pp. 19466-19474

Distribution and threats to Smooth-Coated Otters Lutrogale perspicillata (Mammalia: Carnivora: Mustelidae) in Shuklaphanta National Park, Nepal

- Gopi Krishna Joshi, Rajeev Joshi \& Bishow Poudel, Pp. 19475-19483

Wildlife hunting practices of the Santal and Oraon communities in Rajshahi, Bangladesh - Azizul Islam Barkat, Fahmida Tasnim Liza, Sumaiya Akter, Ashikur Rahman Shome \& M. Fazle Rabbe, Pp. 19484-19491

Ethnozoological use of primates in northeastern India

- Deborah Daolagupu, Nazimur Rahman Talukdar \& Parthankar Choudhury, Pp. 19492-19499

Factors influencing the flush response and flight initiation distance of three owl species in the Andaman Islands

- Shanmugavel Sureshmarimuthu, Santhanakrishnan Babu, Honnavalli Nagaraj Kumara \& Nagaraj Rajeshkumar, Pp. 19500-19508

Birds of Barandabhar Corridor Forest, Chitwan, Nepal

- Saneer Lamichhane, Babu Ram Lamichhane, Kapil Pokharel, Pramod Raj Regmi, Tulasi Prasad Dahal, Santosh Bhattarai, Chiranjibi Prasad Pokheral, Pabitra Gotame,

Trishna Rayamajhi, Ram Chandra Kandel \& Aashish Gurung, Pp. 19509-19526

On some additions to the amphibians of Gunung Inas Forest Reserve, Kedah,

Peninsular Malaysia

- Shahriza Shahrudin, Pp. 19527-19539

Reviews

A review of research on the distribution, ecology, behaviour, and conservation of the Slender Loris Loris lydekkerianus (Mammalia: Primates: Lorisidae) in India

- Mewa Singh, Mridula Singh, Honnavalli N. Kumara, Shanthala Kumar, Smitha D. Gnanaolivu \& Ramamoorthy Sasi, Pp. 19540-19552

Bivalves (Mollusca: Bivalvia) in Malaysian Borneo: status and threats

- Abdulla-Al-Asif, Hadi Hamli, Abu Hena Mustafa Kamal, Mohd Hanafi Idris, Geoffery James Gerusu, Johan Ismail \& Muyassar H. Abualreesh, Pp. 19553-19565

Disentangling earthworm taxonomic stumbling blocks using molecular markers

- Azhar Rashid Lone, Samrendra Singh Thakur, Nalini Tiwari, Olusola B. Sokefun \&

Shweta Yadav, Pp. 19566-19579

A reference of identification keys to plant-parasitic nematodes (Nematoda: Tylenchida) Tylenchomorpha)

- Reza Ghaderi, Manouchehr Hosseinvand \& Ali Eskandari, Pp. 19580-19602

Short Communications

Catalogue of herpetological specimens from Meghalaya, India at the Salim Ali Centre for Ornithology and Natural History

-S.R. Chandramouli, R.S. Naveen, S. Sureshmarimuthu, S. Babu, P.V. Karunakaran \&

Honnavalli N. Kumara, Pp. 19603-19610
A preliminary assessment of odonate diversity along the river Tirthan, Great Himalayan National Park Conservation Area, India with reference to the impact of climate change - Amar Paul Singh, Kritish De, Virendra Prasad Uniyal \& Sambandam Sathyakumar, Pp. 19611-19615

A checklist of orthopteran fauna (Insecta: Orthoptera) with some new records in the cold arid region of Ladakh, India

- M. Ali, M. Kamil Usmani, Hira Naz, Tajamul Hassan Baba \& Mohsin Ali, Pp. 19616-19625

New distribution records of two Begonias to the flora of Bhutan

- Phub Gyeltshen \& Sherab Jamtsho, Pp. 19626-19631

Rediscovery of Aponogeton lakhonensis A. Camus (Aponogetonaceae): a long-lost aquatic plant of India

- Debolina Dey, Shrirang Ramchandra Yadav \& Nilakshee Devi, Pp. 19632-19635

Glyphochloa acuminata (Hack.) Clayton var. laevis (Poaceae): a new variety from central Western Ghats of Karnataka, India

- H.U. Abhijit \& Y.L. Krishnamurthy, Pp. 19636-19639

A cytomorphological investigation of three species of the genus Sonchus L. (Asterales: Asteraceae) from Punjab, India

- M.C. Sidhu \& Rai Singh, Pp. 19640-19644

Dryopteris lunanensis (Dryopteridaceae) - an addition to the pteridophytic diversity of India

- Chhandam Chanda, Christopher Roy Fraser-Jenkins \& Vineet Kumar Rawat, Pp. 1964519648

Notes

First record of Spotted Linsang Prionodon pardicolor (Mammalia: Carnivora:

Prionodontidae) with photographic evidence in Meghalaya, India

- Papori Khatonier \& Adrian Wansaindor Lyngdoh, Pp. 19649-19651

First record of the Eastern Cat Snake Boiga gocool (Gray, 1835) (Squamata: Colubridae) from Tripura, India

- Sumit Nath, Biswajit Singh, Chiranjib Debnath \& Joydeb Majumder, Pp. 19652-19656

First record of the genus Tibetanja (Lepidoptera: Eupterotidae: Janinae) from India - Alka Vaidya \& H. Sankararaman, Pp. 19657-19659

Austroborus cordillerae (Mollusca: Gastropoda) from central Argentina: a rare, little-known land snail

- Sandra Gordillo, Pp. 19660-19662

Intestinal coccidiosis (Apicomplexa: Eimeriidae) in a Himalayan Griffon Vulture Gyps himalayensis

- Vimalraj Padayatchiar Govindan, Parag Madhukar Dhakate \& Ayush Uniyal, Pp. 1966319664

Two new additions to the orchid flora of Assam, India

- Sanswrang Basumatary, Sanjib Baruah \& Lal Ji Singh, Pp. 19665-19670

Wildlife art and illustration - combining black and white ink drawings with colour: some experiments in Auroville, India

- M. Eric Ramanujam \& Joss Brooks, Pp. 19671-19674
Publisher \& Host

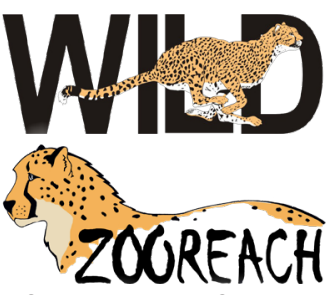

